\title{
Glauconite: An Indigenous and Alternative Source of Potassium Fertilizer for Sustainable Agriculture
}

\author{
Rakesh, S. ${ }^{1 *}$, Ravinder Juttu ${ }^{2}$, Kamalakar Jogula ${ }^{3}$ and Bairi Raju ${ }^{4}$ \\ ${ }^{1}$ Department of Soil Science\& Agricultural Chemistry, Uttar Banga Krishi Viswavidyalaya, Cooch Behar, West Bengal, India \\ ${ }^{2}$ Department of Soil Science \& Agricultural Chemistry, Agricultural College, Aswaraopet, PJTSAU, Telangana State, India \\ ${ }^{3}$ Department of Soil Science \& Agricultural Chemistry, Agricultural College, Warangal, PJTSAU, Telangana State, India \\ ${ }^{4}$ Department of Soil Science \& Agricultural Chemistry, Regional Agricultural Research Station, Jagtial, PJTSAU, Telangana State, \\ India
}

"Corresponding author: rakisavan.940@gmail.com

Received: $23-12-2019$

Revised: 20-04-2020

Accepted: 29-05-2020

\begin{abstract}
Potassium $(\mathrm{K})$ is regarded as a key player in plant growth. It has a significant role in crop productivity as one of the major nutrients. Thus, the addition of $\mathrm{K}$ fertilizers has supreme importance in supplying $\mathrm{K}$ to the plant requirement. Present $\mathrm{K}$ demand is satisfying by highly soluble and concentrated mineral salts; when those salts suddenly introduced into environments, naturally established ecological diversity may become disrupted, ultimately soil fertility is deteriorated. Glauconite is a natural and abundant mineral rich in $\mathrm{K}$ which can be used as a $\mathrm{K}$ fertilizer source for benefiting the agriculture sector. India has the largest deposition of an indigenous glauconitic sandstone which could offer a cheap and locally derived source of slow-releasing $\mathrm{K}$ fertilizer. Usage of glauconite in farming replaces $\mathrm{K}$ fertilizers, viable in terms of economic and environmental perspectives, aids in the provision of additional nutrients along with $\mathrm{K}$, nourishes soil health, and helps in achieving sustainability in agro-ecosystem.
\end{abstract}

Keywords: Potassium, Glauconite, Alternative K source, Natural fertilizer, Sustainable agriculture

Potassium $(\mathrm{K})$ is considered as the most essential macro-nutrient for plant growth after nitrogen and phosphorus as it is involved in important biochemical processes in plants (Zorb et al. 2014). The addition of fertilizer $\mathrm{K}$ becomes necessary in certain soils where it is deficient to maintain the requirement of the plants. The importance of $\mathrm{K}$ and its role in agriculture as well as for human and animal health is well established. Currently, the demand for $\mathrm{K}$ is satisfied by mineral salts of high elemental concentrations (Fixen and Johnston, 2011). Soil available $\mathrm{K}$ is a limiting factor in agriculture; thus $\mathrm{K}$ fertilizers are widely used all over the world (Barre et al. 2008). Indeed, K fertilizers have played a significant role in Indian agriculture to attain and maintain the self-sufficiency in food grain production. In India, import of $\mathrm{K}$ fertilizer costs about $₹ 1000 /$ - crores annually and the additional burden of ₹ 300/- crores towards Govt. subsidy to the agricultural sector for potash fertilizers. In fact, in our country, a million tonnes of $\mathrm{K}$ sources exist but there is practically no production of $\mathrm{K}$ fertilizers. In order to minimize the dependence on imported $\mathrm{K}$ fertilizers, glauconite - a K rich mineral, has been identified as an indigenous alternative source of potassium. The global requirement for $\mathrm{K}$ is projected to increase in the short-term future and alternative sources of K are desirable (Heffer and Prud, 2014) as it benefits the agricultural industry. Adoption

How to cite this article: Rakesh, S., Juttu, R., Kamalakar, J. and Raju, B. (2020). Glauconite: An Indigenous and Alternative Source of Potassium Fertilizer for Sustainable Agriculture. International Journal of Bioresource Science, 7(1): 17-19.

Source of Support: None; Conflict of Interest: None 
of inadequate agricultural practices along with improper management of soil has resulted in land degradation, loss of soil biodiversity,groundwater pollution, low productivity of crops, etc. (Sarkar et al. 2017). Therefore, we need to promote sustainable management strategies to secure food and nutrition security. Glauconitic sandstone has the potential to release plant required $\mathrm{K}$ and can be considered as a natural potassium fertilizer for sustainable agriculture. This article presents a brief outline to explore the alternative source of fertilizer (glauconite).

\section{Depositions of Glauconite Mineral}

In India, glauconite is associated with minerals like sand/sandstones, shale, marl, etc. The deposits are well developed in Son Valley region covering parts of Madhya Pradesh and Uttar Pradesh. In Rajasthan state, glauconitic sandstones/shales occur in Kota, Karauli, Chittorgarh, Jaisalmer, and Barmer districts. Worldwide, glauconitic sandstone is reported from many countries including North America, Australia, Belgium, United Kingdom, and Russia (Amorosia et al. 2007). In Russia, glauconitic sandstone is used as a raw-material to prepare $\mathrm{K}$ fertilizers (Levchenko et al. 2008). Glauconitic sandstone also reported in the Kopet-Dagh Basin of northeast Iran. Photographs of green coloured glauconite deposits in Estonia is shown in Fig. 1.

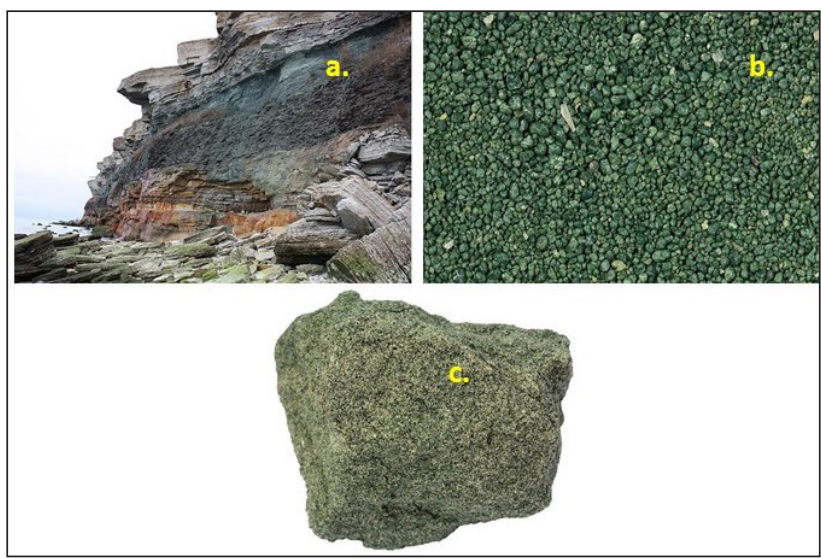

Fig. 1: Glauconite green sandstone deposits in Estonia (a); Glauconite pellets (b); Glauconite sandstone (c) (Source: https://www.sandatlas.org/glauconite/)

\section{Importance of Glauconite in the Agriculture System}

In the past, glauconite been used as a slowacting $\mathrm{K}$ fertilizer in many countries. However, at present, this mineral lost its significance in the world due to the easy availability of highly soluble and concentrated $\mathrm{K}$ minerals. But,due to the nonavailability of any commercially exploitable marine potash deposit in India, it is gaining importance. The efficiency of the glauconitic sandstone mineral could be further improved, through indigenously available technologies to convert it concentrate for the direct usage as $\mathrm{K}$ fertilizer or through various suitable compounds and combinations. The rich $\mathrm{K}$ content and high cation exchange capacity (CEC) of it makes glauconite appealing not only as a source of $\mathrm{K}$ but also as a soil conditioner for agricultural systems. Additionally, it plays a sustainable role in the maintenance of soil fertility as it does not contain any heavy toxic elements above the limits. Glauconite fertilizer not only supplies $\mathrm{K}$ but also phosphorous $(\mathrm{P})$ and other micronutrients such as manganese $(\mathrm{Mn})$, copper $(\mathrm{Cu})$, cobalt $(\mathrm{Co})$, and nickel $(\mathrm{Ni})$ up to a certain extent. The impact of this mineral in agriculture, soil, and yield benefits of its application reported by various researchers is presented in Table 1.

Table 1: Impact of application of glauconite in agriculture

\begin{tabular}{|c|c|}
\hline Impact & References \\
\hline $\begin{array}{l}\text { Republic of the Congo, use glauconite as } \\
\text { a fertilizer to increase the productivity of } \\
\text { farms. }\end{array}$ & $\begin{array}{l}\text { Giresse and } \\
\text { Jamet (1982) }\end{array}$ \\
\hline $\begin{array}{l}\text { Glauconitic mineral can be used directly } \\
\text { as a fertilizer source to enhance the } \\
\text { productivity of farms. }\end{array}$ & $\begin{array}{l}\text { Coroneos et al. } \\
(1996)\end{array}$ \\
\hline $\begin{array}{l}\text { A higher potassium content and } \\
\text { superior yields were resulted after using } \\
\text { glauconite as K fertilizer in millet farms } \\
\text { of Madhya Pradesh }\end{array}$ & $\begin{array}{l}\text { Rao and Rao } \\
\text { (1999) }\end{array}$ \\
\hline $\begin{array}{l}\text { Positive effect on potato mineral nutrition } \\
(\mathrm{N}, \mathrm{P}, \mathrm{K}) \text {, potato yield increased by } \\
25-30 \% \text { and stimulate plant adaptation } \\
\text { capability, especially drought resistance. }\end{array}$ & $\begin{array}{l}\text { Abdolzadeha } e \\
\text { al. (2011) }\end{array}$ \\
\hline $\begin{array}{l}\text { Glauconite as fertilizer will protect the } \\
\text { cultivated soils from acidification and } \\
\text { salinization }\end{array}$ & $\begin{array}{l}\text { El-Habaak et al. } \\
\text { (2016); Rudmin } \\
\text { et al. (2017) }\end{array}$ \\
\hline $\begin{array}{l}\text { Addition of glauconitolite to soil has } \\
\text { significantly increased the grain yield of } \\
\text { wheat crop. }\end{array}$ & $\begin{array}{l}\text { Rudmin et al. } \\
\text { (2019) }\end{array}$ \\
\hline
\end{tabular}

\section{Limitations and Recommendations}

It seems that due to the easy availability of highly soluble marine potash salts, no serious efforts have 
been made anywhere else in the world regarding making glauconite as a fertilizer except in India because it contains only a meagre 4 to $8 \% \mathrm{~K}_{2} \mathrm{O}$.

Considering the already established use of glauconitic as $\mathrm{K}$ fertilizer, the encouraging outcomes of its direct application obtained in Uttar Pradesh and West Bengal by Indian Agricultural Universities, the following recommendations are made:

- Initially, glauconite can be combined with other chemical fertilizers and compost manure, but with no chemical fertilizer as a primary source of $\mathrm{K}$ be used; so that the performance of glauconitic sandstone may be widely established in the Indian agricultural fields.

- Direct application of glauconite should be started immediately, especially in the acidic soils of Uttar Pradesh, Rajasthan, Karnataka, Madhya Pradesh, and Andhra Pradesh which are located in the vicinity of the area of occurrences of glauconitic sandstone.

- Manual extraction of glauconitic sandstone at a small scale level should be mechanized with advanced mining techniques to improve productivity and economics.

\section{CONCLUDING REMARKS}

Burgeoning population demanding more production of food grains. Potassium $(\mathrm{K})$ is being one of the major nutrients which are most essential for crop productivity. Glauconite as a natural K source is eminently useful in improving soil fertility, crop productivity as well as ensuring food security and environmental sustainability. Due to its low cost, accessibility, and lower contamination, glauconite is best suitable in soil health management and economic perspective. Indeed, glauconite will provide an effective, economic, and alternative indigenous source of $\mathrm{K}$ fertilizer to the Indian agricultural sector if it is used judiciously. Also, an import of $\mathrm{K}$ fertilizers will be drastically reduced and aids in saving foreign exchange to the extent of $50 \%$ of the present expenditure of $₹ 1300$ crore (import and subsidy). The indigenous natural resources of glauconite in the country will be effectively utilized by developing industries and also aids in the provision of research activities $(R \& D$ works) and provide employments by ensuring the socio-economic development of our country.

\section{REFERENCES}

1. Abdolzadeha, E.K.A., Sadeghipoura, H.R. and Aminei, A. 2011. The potential of glauconitic sandstone as a potassium fertilizer for olive-plants. Journal of Agronomy and Soil Science, 58(9): 983-993.

2. Amorosi, A., Sammartino, I. and Tateo, F. 2007. Evolution patterns of glaucony maturity: A mineralogical and geochemical approach. Deep Sea Research Part II: Topical Studies in Oceanography, 54(11-13): 1364-1374.

3. Barre, P., Velde, B., Fontaine, C., Catel, N. and Abbadie, L. 2008. Which 2:1 clay minerals are involved in the soil potassium reservoir? Insights from potassium addition or removal experiments on three temperate grassland soil clay assemblages. Geoderma, 146: 216-223.

4. Coroneos, C., Hinsinger, P. and Gilkes, R.J. 1996. Granite powder as a source of potassium for plants: a glasshouse bioassay comparing two pasture species. Fertilizer Research, 45(2): 143-152.

5. El-Habaak, G., Askalany, M., Faraghaly, M. and AbdelHakeem, M. 2016. The economic potential of El-Gedida glauconite deposits, El-Bahariya Oasis, Western Desert, Egypt. Journal of African Earth Sciences, 120: 186-197.

6. Fixen, P.E. and Johnston, A.M. 2011. World fertilser nutrient reserves: a view to the future. Journal of Science of Food and Agriculture, 92: 1001-1005.

7. Giresse, P. and Jamet, R. 1982. Cassava fertilizer trials with glauconitic sediments from the Congo. Pedologie, 19: 283-292.

8. Heffer, P. and Prud, M. 2014. Fertilizer Outlook 2014-2018. International Fertiliser Industry Association, pp. 26-28.

9. Levchenko, E., Ptyk-Kara, N. and Levchenko, M. 2008. Glauconite deposits of Russia: Perspectives of development. In: Abstracts. International Geological Congress, Oslo, pp. 6-14.

10. Rao, C.S. and Rao, A.S. 1999. Characterization of indigenous glauconitic sandstone for its potassium supplying potential by chemical, biological, and electroultraltration methods. Communications in Soil Science and Plant Analysis, 30(7-8): 1105-1117.

11. Rudmin, M. et al. 2019. An investigation of plant growth by the addition of glauconitic fertilizer, Applied Clay Science DOI: 10.1016/j.clay.2019.105178

12. Rudmin, M., Banerjee, S., Mazurov, A., Makarov, B. and Martemyanov, D. et al. (2017). Economic potential of glauconitic rocks in Bakchar deposit (S-E Western Siberia) for alternate potash fertilizer. Applied Clay Science, 150: 225-233.

13. Sarkar, D., Shikha, Rakesh, S., Ganguly, S. and Rakshit, A. (2017). Management of increasing soil pollution in the ecosystem. Advances in Research, 12(2): 1-9.

14. Zorb, C., Senbayram, M. and Peiter, E. 2014. Potassium in agriculture - status and perspectives. 
